Sandra Jednak ${ }^{1}$

Dragana Makajić-Nikolić

Dragana Kragulj ${ }^{3}$

Mirko Vujošević
JEL: 011, P27, L16, C61, G11

DOI: 10.5937/industrija44-9572

UDC: $330.341 .4(497.11)$

330.342

Original Scientific Paper

\title{
The Effects of Economic Activities Diversification on Development: the Perspective of Serbia
}

Article history:

Received: 21 November 2015

Sent for revision: 5 February 2016

Received in revised form: 20 April 2016

Accepted: 5 May 2016

Available online: 11 July 2016

\begin{abstract}
Each economy specializes in certain economic activities depending on the development level and availability of resources. During their development, countries undergo sectoral transformation. In order to achieve a higher level of economic development, it is necessary for a country to diversify its economic activities and determine which economic activities should be invested in. The aim of this paper is to analyse the effects of economic structure and diversification activities on the development of Serbia for the period 2007-2012. Optimization model has been used to present diversification of activities. Furthermore, the efficiency frontier is used to show returns, risks and correlation among activities. The results show that the economic activities - Mining and quarrying, Public administration and defence, Compulsory social security, Other service activities, Financial and insurance activities, Arts, entertainment and recreation should be drivers of economic growth, because they provide a balance between growth and security regarding GVA in economic activities.
\end{abstract}

Keywords: economic activities, development, diversification, portfolio, Serbia

\section{Efekti diversifikacije ekonomskih aktivnosti na razvoj: primer Srbije}

Apstrakt: Zavisno od raspolozivosti resursa i nivoa razvoja, svaka zemlja je specijalizovana u određenim delatnostima. Tokom razvoja, zemlje sprovode

\footnotetext{
${ }^{1}$ University of Belgrade, Faculty of Organizational Sciences, sjednak@fon.bg.ac.rs

2 University of Belgrade, Faculty of Organizational Sciences

${ }^{3}$ University of Belgrade, Faculty of Organizational Sciences

${ }^{4}$ University of Belgrade, Faculty of Organizational Sciences 
Jednak S. et al.: The Effects of Economic Activities Diversification on Development...

sektorsku transformaciju. U cilju da postignu viši nivo ekonomskog razvoja, neophodno je da svaka zemlja diversifikuje ekonomske aktivnosti i odredi u koje ekonomske aktivnosti treba ulagati. Cilj ovog rada je da analizira efekte ekonomske strukture i diversifikaciju aktivnosti na razvoj Srbije u period 20072012.godine. Model optimizacije je korišćen da se pokaže diversifikacija aktivnosti. Nadalje, granica efikasnosti je korišćena da se pokažu prinosi, rizici i korelacija između aktivnosti. Rezultati pokazuju da ekonomske aktivnosti Rudarstvo, Državna uprava i obavezno socijalno osiguranje, Ostale uslužne delatnosti, Finansijske delatnosti i delatnosti osiguranja, Umestnost, zabava i rekreacija treba da budu pokretači ekonomskog rasta, zato što obezbeđuju balans između rasta i sigurnosti prema GVA u ekonomskim aktivnostima.

KIjučne reči: ekonomske aktivnosti, razvoj, diversifikacija, portfolio, Srbija

\section{Introduction}

In most countries, there are target economic activities that serve as drivers to achieve a higher level of development. However, instability and exposure to enhanced risk lead to a demand for economic diversification. Thus, the economy becomes less vulnerable to fluctuations and changes. Various sources of income allow: resilience, stability and sustainability (Shediac et al., 2011). After the global economic crisis and the instability that followed, the main objectives of each economy have been stability, sustainable income and reforms. Only by fulfilling these goals, sustainable development can be attained. Advanced economies have succeeded in achieving diversification, while other, developing countries are still in the process of obtaining economic diversification activities.

Some of the main issues the developing countries deal with are structural changes and economic diversification. These countries are constantly making efforts to diversify their economic activities, industries and markets. Diversification promotes growing output and income from a wide range of economic activities, mitigating any possible risks, as well. Likewise, spreading employment and investment over different economic activities is one of the advantages of such process. Diversification is particularly important for the countries that have just a few trading partners. Their growth is mainly based on export and the source of investment is foreign capital. Along these lines, while poor and developing countries develop diversification, especially export, they also obtain higher income (Cadot et al., 2013). Moreover, countries have to establish institutions and regulatory frameworks in order to reduce impact of exogenous factors. On one hand, diversification increases income, employment, growth and improves structure, while on the other it minimizes 
Jednak S. et al.: The Effects of Economic Activities Diversification on Development...

the impact of global external changes. This process supports economic stability and the conditions for sustainable development.

According to IMF report (2014), sectoral transformation and diversification have a significant role in obtaining economic growth in developing countries. The highest influence is related to the changes in export, domestic production and trade partners' structure. Structural, regulatory and institutional changes, stabilization policy package, export increase and stronger competition are drastic changes that lead an economy from a turbulent to a stable one (Cimoli and Katz, 2003). Hesse (2009) reported that economic development is basically a process of structural transformation and that export diversification plays an important role in this process. Hesse also claimed that there is a positive relationship between diversification and income. According to Murshed and Serino (2011) countries that are specialized in export of natural resources can enhance economic growth by economic and export diversification. Alonso-Carrera and Raurich (2010) showed that differences in sectors' structure, together with production factors endowment can influence achieving different economic growth rates. Jaimovich (2011) proposed a model where it is shown that differentiation of sectors, along with operation of financial markets can shape the patterns of development. According to Gilchrist et al. (1995) regional industrial diversification policies have positive roles in growth of economic welfare. Iordan and Chilian (2014) stated that sectoral structure has an important role in development on both national and sub-national levels. Additionally, Fu et al. (2010) claimed that in developing countries industrial diversity is positively associated with unemployment, while industrial specialization can decrease unemployment. Sector reallocation, along with entrepreneurship has positive influence on economic growth (Noseleit, 2013). Besides, allocation in manufacturing systems has advantages in obtaining positive performances (Cvetkovic-Lecic et al., 2010). Therefore, according to various research papers, it could be concluded that sector structure and diversification undoubtedly have influence on economic growth and development.

The research presented in the paper has been driven by the following main research questions: 1) What kind of contribution do economic activities' structure make to the economic growth rate?; 2) Which economic activities have the highest contribution to growth rate i.e. share of GDP?; 4) Does economic activities' diversification contribute to higher economic growth and development? and 3) Which economic activities should be invested in? According to the research questions, the aim of this paper is to analyse the effect of economic activities' structure and diversification on the development of Serbia. The purpose of this paper is the analysis and optimization of investments into certain economic activities that contribute the most to achieving economic development. Furthermore, investment problem is 
Jednak S. et al.: The Effects of Economic Activities Diversification on Development...

formulated as a portfolio optimization problem based on Markowitz' theory of mean-variance optimization.

The paper is structured as follows: Section 2 provides a short summary of economic activities' structure transformation during economic development. This section also provides an overview of economic growth and development strategies of Serbia. The section describes sectors 'structure, transformation and developing strategies and their influence on development. Optimization model is set out in section 4 . The following section illustrates the application of the proposed model to the data for the period 2007 - 2012. Finally, concluding remarks are presented in the last section.

\section{Economic activities structure transformation during economic development}

Productivity rise, favourable natural resources distribution, and physical and human capital contribute to economic growth and development (Cypher and Dietz, 2009). In less-developed and developing countries specialization in raw material exports (Massol and Banal-Estanol, 2014) and agricultural sector are the determinants of economic growth. However, along with economic development the sector structure undergoes certain changes. Economic development is related to increasing the share of industry sector, and decreasing the share of agriculture in GDP (Punnyasavatsut and Coxhead, 2002; Arandjelovic et al., 2013, Savic, 2014). The development of industry sector influences the service sector to gain more importance. Moreover, the industry sector becomes more profitable than agriculture. Factors like technologies, knowledge, human and physical capital help establishing more efficient industry sector. Furthermore, development of industry sector causes changes in export structure. Development of industry sector also enables export of industrial, knowledge and technology supported products (Jednak et al., 2014). Along with a higher level of economic development, service sector becomes predominant. The countries on such a high level of development obtain development by synergy, cooperation, and coordination of knowledge, innovation, and advanced technologies. The development of highly developed countries rests on knowledge-based industries and certain public sector activities (Jednak, 2012). The change of sectors 'structure is usual during economic development, which is a complex process and should be measured by various economic, social and technology indicators (Milenkovic et al., 2014).

\subsection{Case study of Serbia}

Serbia is one of the countries that belong to the Western Balkans, South-East Europe. It is a member of the UN and CEFTA. Serbia is also a candidate 
Jednak S. et al.: The Effects of Economic Activities Diversification on Development...

country for EU membership. According to the World Bank (2013) Serbia is a developing country - an upper-middle income economy ( $\$ 5,730 \mathrm{GNI}$ per capita). Since 2000, Serbia has had a transitional economy. During the period Serbia has carried out economic reforms and made many structural and institutional reforms. It has established market economy, higher competitiveness, supportive business environment and investment climate. However, economic crisis has slowed down economic reforms that were very fast until then. Foreign direct investments and borrowing are considered to be a significant source of economic growth and development in this country. Due to foreign direct investments Serbia maintains its production and export growth. The greatest share in production belongs to service sector that is followed by industry and agriculture sectors. Export is mostly based on automobile, food processing and metal industries.

Over the past fifteen years, Serbia has changed its strategy of economic growth and development. In the period 2001-2008, economic growth and development of Serbia used to rest on a large-scale domestic demand, import and the need for foreign funds. Economic growth was achieved as a consequence of the undergone institutional reforms, economic and social policy and permissive environment in the international capital market (Djordjevic and Veselinovic, 2010). At the time, Serbia was following the strategy of economic growth and development (2001-2008) that rested on investment in the following sectors: 1) traffic, storage and connections, 2) trade and 3) financial brokerage. These economic activities were the basic components of the economic growth and amounted to 30\% GDP. In year 2001 agriculture, hunting, forestry, fishery and manufacturing comprised $32 \%$ GDP, but their share decreased in 2008 to 24\% GDP (Group of authors, Postkrizni model ekonomskog rasta i razvoja Srbije 2011-2020, 2010). The influence of the economic crisis was reflected on the drop in economic performances (Izvestaj o razvoju Srbije, 2010). When the EU had adopted new "Europe 2020" strategy, Serbia worked out a new model of growth for Serbia 2020. The new Serbian growth model was changed from a consumeroriented to pro-investment and export-oriented economic growth. The share of export in GDP was about 25 per cent, and with a new strategy it should be double or triple (The World Bank, 2012). The growth of this new strategy is based on the reform in the public sector, economy restructuring and infrastructure development. The main objectives of this model are - job creations, poverty reduction, investing in knowledge and technology, better labour market performance, export-based growth and energy efficiency. Whether such objectives are going to be accomplished or not depends on fixed investment increase, reducing the share of public consumption in GDP, raising the share of export in GDP and decreasing current account deficit.

Fiscal policy of Serbia for 2013 (Nacrt fiskalne strategije za 2013. godinu sa projekcijama za 2014. i 2015.godinu), envisages the following economic 
Jednak S. et al.: The Effects of Economic Activities Diversification on Development...

activities to be the basic ones for economic growth and development: agriculture, mining and power industry, transport, telecommunications, tourism, health care, education and science. According to Statistical Office of the Republic of Serbia report of Serbian economic activity for 2012, the greatest growth of GDP was recorded for the following economic activities: Information and communication; Professional, scientific, innovation, technical activities and Administrative and service activities. On the contrary, the greatest production reduction was in the sectors of Agriculture, forestry and fishery; other service activities and in the accommodation and food services activities. The drop in industrial production was $3.4 \%$. This fall was mostly influenced by the decrease of production in the sectors of power, gas and steam. Agricultural production also declined for $17.5 \%$. Furthermore, there was a decrease in construction, retail, transport and storage activities, while the telecommunication and wholesale activities recorded growth.

Based on the overview of Serbian development and developing strategies, the authors will attempt to provide answers to the research questions. The answers to the questions - which economic activities should be the basis of Serbian economic development and where to invest in - have been analysed in Markowitz' theory of mean-variance optimization. Likewise, the question concerning economic activities' diversification is explained by the efficiency frontier.

\section{Methodology}

The mean-variance portfolio (MVP), proposed by Markowitz (1952), marks the beginning of the modern financial portfolio theory. It is based on two conflicting criteria: the risk of a portfolio, which should be minimised, and the expected return of the portfolio, which should be maximised. The return is the chosen performance of an investment, while the risk of a portfolio is measured by the variance of return (Cornuejols, 2011).

Although MVP was originally developed for financial portfolios, it has been applied to various economic fields. In this paper, the MPV is applied to solve the economic problem: diversification of economic activities in Serbia. Regional diversification is an economic issue where portfolio optimization is widely applied. Since the seventies, the problem of resource allocation among different regions within a country has been observed as portfolio optimization problem. The analogy between a stock portfolio and a regional economy was established by Conroy (1974). This analogy is based on the fact that the resources which a region invests in any industry generate a variety of returns (employment, wage income, non-wage income or their weighted subsets) which are essentially stochastic. Conroy (1974) claimed that one must think of 
Jednak S. et al.: The Effects of Economic Activities Diversification on Development...

selecting an industrial portfolio as a whole, instead of each industry per se. Several years later, based on this concept, Louis (1980) used Markowitz portfolio theory for regional diversification. Industrial diversification of nine regions in Canada was measured in order to compare the existing industrial portfolio with an efficient potential portfolio. Brewery (1985) empirically proved that the portfolio variance measure, suggested by Conroy, has a great power to explain differences in economic instability across regions. The similar conclusion about the possibilities of models that incorporate elements of portfolio theory to express relationship between a region's changing economic structure and performances was given by Siegel et al. (1995). A portfolio management framework, as a basis for developing regional economic strategies, was also given in (Lande, 1994). The authors proposed the US employment portfolio by considering employment growth rates and employment variance. Starting with the assumption that the regional economy has a lot in common with an investment portfolio, Spelman (2006) applied portfolio theory to the data on the economies of the 316 US metropolitan areas. The goal was to improve local economic development policy which included both stability and growth.

Moreover, portfolio optimization concept is widely applied to individual industry sectors. Real estate portfolio diversification, based on property type and region by measuring the correlations between time series of real estate returns aggregated by region, was determined in (Eichholtz and Hoesli, 1995). The authors constructed efficient frontiers for diversification within each property type across all regions and vice versa and the efficient frontiers for full diversification across all property types and regions in the cases of the USA and the UK. Barry and Kearney (2006) analyzed high-technology and lowtechnology sectors and constructed an efficient frontier of optimal configuration of employment growth and risk. Junning and Leung (2006) observe Hawaii's agricultural sector like a portfolio composed of a variety of individual agricultural industries. Using the data about production value as a measure of general performance of the agricultural sector, the authors applied portfolio analysis to assess the growth and stability of the agricultural industries. Recently, a large amount of research concerning the application of portfolio optimization in the energy sector has been conducted. Rodoulis (2010) used optimization portfolio theory to evaluate the planed electricity generation mix consisting of oil, natural gas, wind, and coal energy for the country of Cyprus. A similar research was done by Cucchiella et al. (2012) in the case of investment in Italian renewable energies: biomass, wind, hydro and photovoltaic. As in the previous research, the goal was to minimize energy risk and energy dependency. Westner and Madlener applied mean-variance portfolio analysis on the combined heat and power (CHP) portfolio in the case of four European countries: Germany, France, Italy and the UK (2010), where regional diversification was investigated as well as in the case of Germany 
Jednak S. et al.: The Effects of Economic Activities Diversification on Development...

(2011), where different CHP technologies and the expected development of CHP generation in Germany were considered.

The basic portfolio optimization model considers initial sum for investment and $n$ securities with random returns. The goal is to determine an investment proportion vector $x=\left(x_{1}, \ldots, x_{n}\right)$, also called a portfolio, which specifies the proportions of the initial sum to be invested in the $n$ securities (Cornuejols, 2011). Natural condition relating to $x$ is:

$$
\sum_{i=1}^{n} x_{i}=1
$$

Let $\mathrm{S}$ be the set of all feasible investment proportion vectors:

$$
S=\left\{x_{i} \mid \sum_{i=1}^{n} x_{i}=1, \alpha_{i} \leq x_{i} \leq \omega_{i}, i=1, \ldots, n\right\}
$$

where the $\alpha_{i}$ and $\omega_{i}$ are lower and upper bounds on the $x_{i}$.

The vector $\mu=\left(\mu_{1}, \ldots, \mu_{n}\right)$ specifies the expected returns of the $n$ securities to be realised at the end of the observing period. Since we investigate the problem of investment in different economic activities, taking into account growth of GVA, $\mu_{i}$ represents the expected growth of GVA of the $i$-th activity, $i=1, \ldots, n$. Portfolio return can be expressed as:

$$
E[x]=\sum_{i=1}^{n} \mu_{i} x_{i}
$$

The overall risk of the portfolio is then defined as a quadratic combination of the covariance of the activities included in it:

$V[x]=\sum_{i=1}^{n} \sum_{j=1}^{n} x_{i} \sigma_{i j} x_{j}$

where $\sigma_{i j}$ denotes the covariance for the activities $i$ and $j$.

Two optimization models can be formulated: the expected return maximization for a given level of risk (5), or the risk minimization for a desired growth of GVA (6). 
Jednak S. et al.: The Effects of Economic Activities Diversification on Development...

$\max \sum_{i=1}^{n} \mu_{i} x_{i}$

s.t.

$\sum_{i=1}^{n} \sum_{j=1}^{n} x_{i} \sigma_{i j} x_{j} \leq \sigma^{2}$

$x_{i} \in S, i=1, \ldots, n$

$\min \sum_{i=1}^{n} \sum_{j=1}^{n} x_{i} \sigma_{i j} x_{j}$

s.t.

$\sum_{i=1}^{n} \mu_{i} x_{i} \geq R$

$x_{i} \in S, i=1, \ldots, n$

where $\sigma^{2}$ and $R$ are the target value for the variance of the portfolio and expected portfolio growth.

The solution of portfolio optimization models will give the activities diversification. In addition, by solving (5) for different desired values of $\sigma$ or (6) for different desired values of $\mathrm{R}$, efficient frontier can be produced. A graphical illustration of the efficient frontier is given in Figure 1. The shape of the efficient frontier for the particular data depends on the returns, risks and the correlation among them (Fabozzi et al., 2007).

Figure 1. Feasible and Markowitz Efficient Portfolios (Fabozzi et al., 2007)

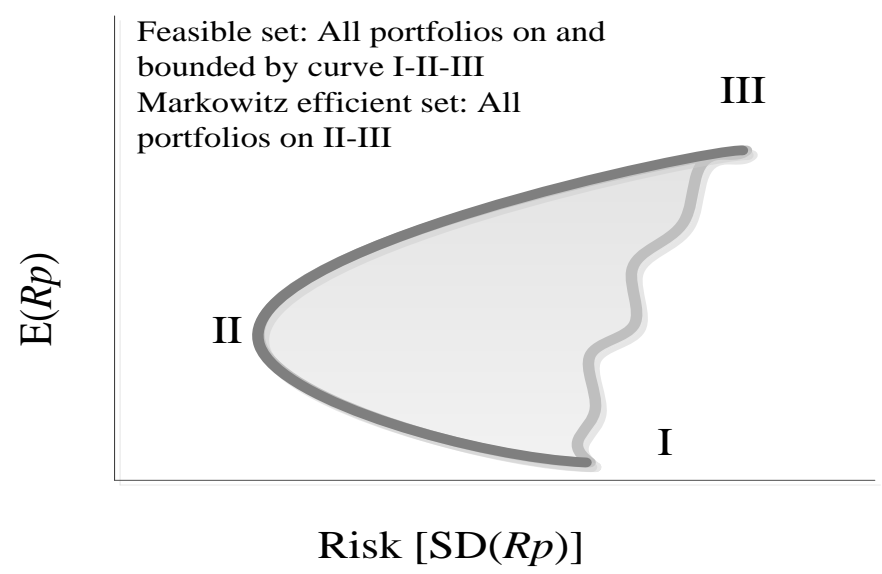

Industrija, Vol.44, No.2, 2016 
Jednak S. et al.: The Effects of Economic Activities Diversification on Development...

\section{Results and discussion}

The data are used from the Statistical Yearbook of Serbia for 2012. Only one indicator was taken as the basis for the model Markowitz meanvariance portfolio. The constraint was that some of the indicators were not available in databases for a longer period than it is observed. Also, the limitation was that some indicators, like employment, were calculated by different methodology and the economic activities classification was different for the observed period. The reason for these differences is harmonization with the EU statistics methodology. The data presented here are given at the level of the gross value added - GVA for the period 2007-2012. GVA is the total value of output of goods and services produced less than intermediate consumption. GVA is the value of production of goods and services in economic activity, industry of an economy and measures the contribution of each economic activity, industry to the GDP. GVA is starting point for calculating GDP. GDP is the sum of gross value added of economic activities/ industries, plus taxes on products and imports and minus subsidies on products. Therefore, GVA is used as a measure of value of goods and services of economic activities.

Table 1 provides an overview of share of the observed activities in total GVA from 2007 to 2012.

Table 1 Annual share of economic activities in total GVA

\begin{tabular}{|c|c|c|c|c|c|c|c|c|c|c|c|c|c|c|c|c|c|c|c|c|}
\hline & A & B & C & D & E & F & G & H & I & J & K & L & M & N & O & P & Q & R & S & T \\
\hline 2007 & 8.6 & 1.2 & 14.1 & 2.7 & 1.1 & 4.4 & 10.1 & 4.7 & 1.1 & 3.8 & 2.8 & 9.5 & 4.1 & 1.5 & 4.0 & 4.2 & 5.3 & 0.8 & 0.9 & 0.1 \\
\hline 2008 & 8.9 & 1.2 & 14.0 & 2.6 & 1.0 & 4.7 & 10.4 & 4.6 & 1.0 & 4.0 & 2.9 & 9.7 & 4.2 & 1.6 & 3.4 & 4.3 & 5.4 & 0.9 & 0.9 & 0.1 \\
\hline 2009 & 8.0 & 1.3 & 13.6 & 3.2 & 1.1 & 4.1 & 9.5 & 4.7 & 1.0 & 4.2 & 3.1 & 10.9 & 3.6 & 1.4 & 3.3 & 4.4 & 5.5 & 1.3 & 1.4 & 0.1 \\
\hline 2010 & 8.5 & 1.5 & 13.5 & 3.1 & 1.2 & 4.0 & 9.3 & 4.6 & 1.0 & 4.3 & 3.3 & 11.2 & 3.4 & 1.5 & 3.5 & 4.2 & 5.2 & 1.3 & 1.3 & 0.1 \\
\hline 2011 & 9.1 & 1.6 & 14.0 & 3.5 & 1.2 & 4.2 & 9.2 & 4.5 & 1.0 & 4.3 & 3.0 & 10.7 & 3.5 & 1.5 & 3.5 & 3.9 & 5.6 & 0.9 & 1.1 & 0.1 \\
\hline 2012 & 8.3 & 1.7 & 14.4 & 3.3 & 1.2 & 4.1 & 9.5 & 4.7 & 1.0 & 4.4 & 3.2 & 10.0 & 3.6 & 1.5 & 3.8 & 3.9 & 5.4 & 0.9 & 1.2 & 0.1 \\
\hline
\end{tabular}

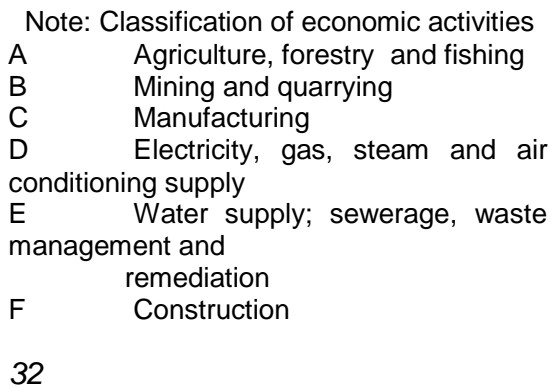

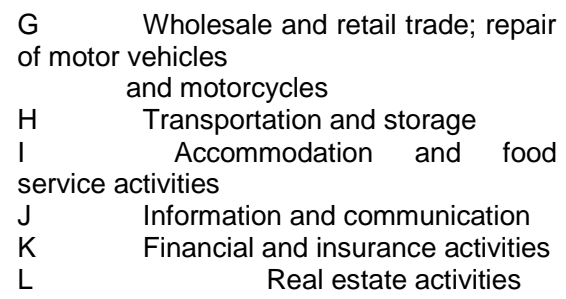

Industrija, Vol.44, No.2, 2016 

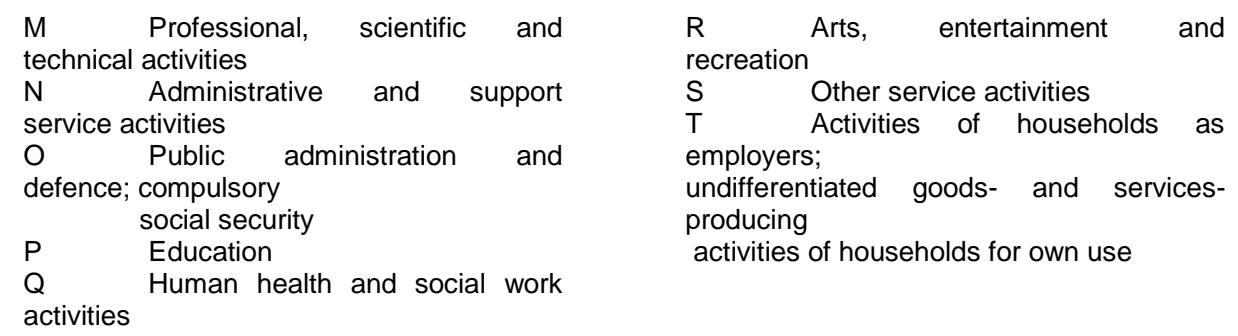

Research questions 1\&2: What kind of contribution do economic activities' structure make to the economic growth rate? Which economic activities have the highest contribution to growth rate i.e. share of GDP?

During the observed period, Serbia made changes in tax rates, and because of that, taxes and subventions are excluded. So, Table 1 presents shares of economic activities in total GVA not in GDP. As indicated in Table 1, the share of economic activities in total GVA is almost unchanged in the observed period. In addition, no economic activity gained a significant increase or decrease in relation to other economic activities. The largest share in total GVA belongs to Manufacturing (C), Wholesale and retail trade; repair of motor vehicles and motorcycles (G), Real estate activities (L) and Agriculture, forestry and fishing (A), while the lowest share belongs to Mining and quarrying (B), Electricity, gas, steam and air conditioning supply (E), Accommodation and food service activities (I), Arts, entertainment and recreation (R), Other service activities (S) and Activities of households as employers; undifferentiated goods- and services-producing activities of households for own use (T). According to Table 1, about $50 \%$ of total GVA belongs to Manufacturing $(C)$, Wholesale and retail trade; repair of motor vehicles and motorcycles(G), Real estate activities (L), Agriculture, forestry and fishing (A) and Human health and social work activities (Q). Of that share (about $50 \%$ of total GVA), service based economic activities have the share of about 25\%, followed by Manufacturing (C) $14 \%$ and finally Agriculture, forestry and fishing (A) $9 \%$. The greatest share belongs to Manufacturing (C). Although there was a decline in some economic activities during the observed period, the structure of economic activities remained the same and did not significantly affect the economic growth rate. Furthermore, based on these data, it can be concluded that the largest share of total GVA belongs to economic activities that are specified by strategies of economic growth and development.

Research questions 3: Does economic activities' diversification contribute to higher economic growth and development?

There are papers that analyse the advantages of both specialization and diversification. However, today, after the global economic crisis and different kinds of crises that struck every economy, there is a need for economic 
Jednak S. et al.: The Effects of Economic Activities Diversification on Development...

diversification. In the world of almost everyday changes, diversity increase is the condition for obtaining stability and sustainable economic growth. The presence of various industries in the economy enables balance in both income and employment across the economic activities. Serbia is a developing country that is exposed to external changes and whose growth and development is mostly based on foreign capital should do diversification of economic activities, investments and exports. Thus Serbia protects its economy from higher risk of foreign influence. The state and role of economic activities diversification in Serbia are analysed. The following results have been obtained.

The expected GVA annual growth rate (EGR), standard deviations (SD), and correlations of the observed 20 economic activities are presented in Table 2. The highest annual GVA growth rates are in economic activities, Other service activities (S) and Mining and quarrying (B). These are economic activities with small but growing share: $0.9-1.2 \%$ in the observed period for Other service activities (S) and 1.2-1.7\% for Mining and quarrying (B) (see Table 1). The annual grow rates of these two activities are about $16 \%$ with relatively small standard deviations, especially in the case of Mining and quarrying (B). On the other hand, economic activities with the highest share are: Manufacturing (C), Real estate activities (L) and Wholesale and retail trade; repair of motor vehicles and motorcycles (G), are among economic activities with the lowest growth rates $(0.086,0.094$ and 0,07 for $C$, $L$ and $G$, respectively).

The correlation varies from high positive 0.98 (Manufacturing $(C)$ and Construction $(F)$ ) to high negative -0.9 (Real estate activities $(L)$ and Public administration and defence; compulsory social security $(\mathrm{O})$ ). The average correlation for all activities is 0.24 . There are four activities with the mean correlations above 0.45: Construction (F) (0.49), Information and communication (J) (0.48), Manufacturing (C) (0.46) and Wholesale and retail trade; repair of motor vehicles and motorcycles ( $G(0.45)$. The lowest mean correlation is in Other service activities (S) $(-0.25)$ which is negatively correlated with the majority of activities. Among the activities that are negatively correlated with most of activities and have negative mean correlation are also: Arts, entertainment and recreation $(R)(-0.22)$. 
Table 2. Annual GVA growth rate, standard deviations, and correlations between 20 economic activities

\begin{tabular}{|c|c|c|}
\hline$\vdash$ & 范 & \\
\hline$\infty$ & \begin{tabular}{ll}
$\frac{0}{0}$ & \multicolumn{2}{c}{} \\
& 0
\end{tabular} & $\stackrel{\substack{\infty \\
\hdashline}}{\infty}$ \\
\hline$\propto$ & 誉 & $\stackrel{8}{\circ} \underset{\infty}{\infty}$ \\
\hline 0 & 总 & 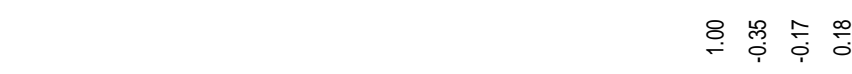 \\
\hline a & 营 。 & 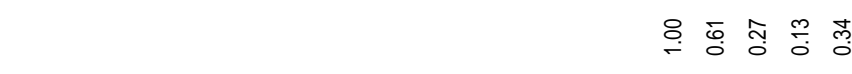 \\
\hline 0 & $\begin{array}{ll}0 \\
0 \\
0\end{array}$ & 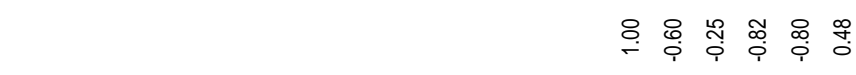 \\
\hline$z$ & 总哭 & 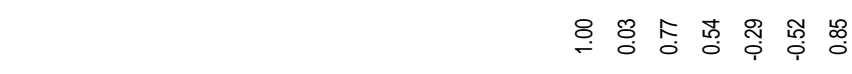 \\
\hline$\Sigma$ & 훙 : & 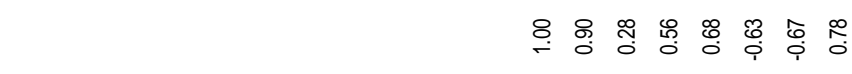 \\
\hline- & 营 总 & 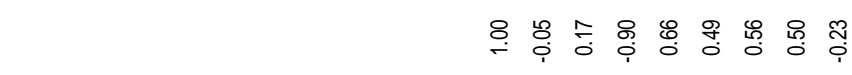 \\
\hline 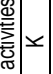 & 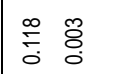 & 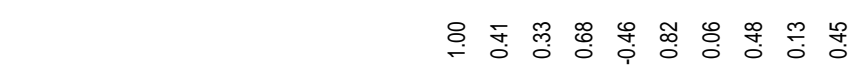 \\
\hline$>$ & 总学 & 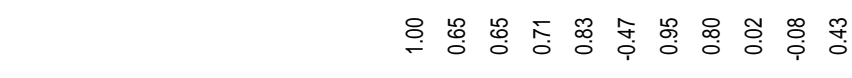 \\
\hline- & 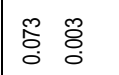 & 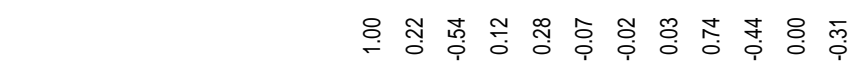 \\
\hline$I$ & $\begin{array}{ll}\hat{0} & 0 \\
0 & 0 \\
0\end{array}$ & 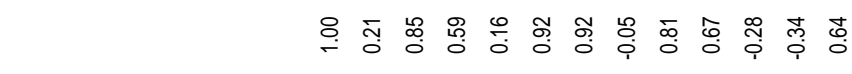 \\
\hline o & $\begin{array}{ll}0 & 0 \\
0 & 0 \\
0 & 0\end{array}$ & 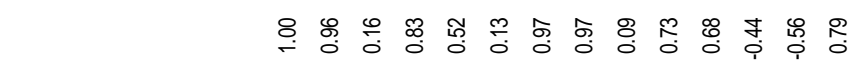 \\
\hline 4 & 监 & 只 \\
\hline ш & 号 & 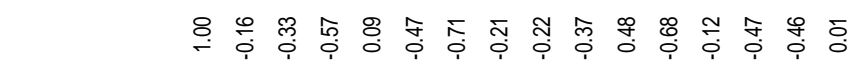 \\
\hline$a$ & $\frac{5}{0}$ & 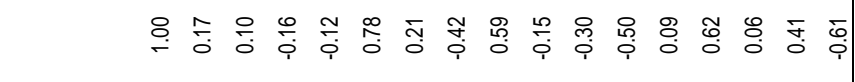 \\
\hline 0 & $\stackrel{\circ}{\circ} \stackrel{\circ}{\circ}$ & 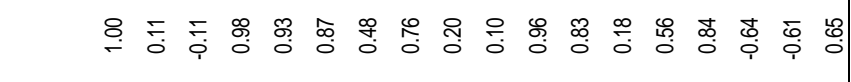 \\
\hline$\infty^{\infty}$ & $\frac{\circ}{0} \frac{0}{0}$ & 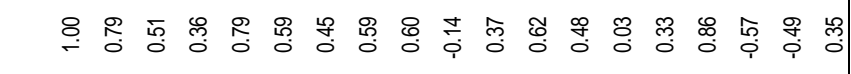 \\
\hline$|\varangle|$ & 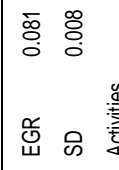 & 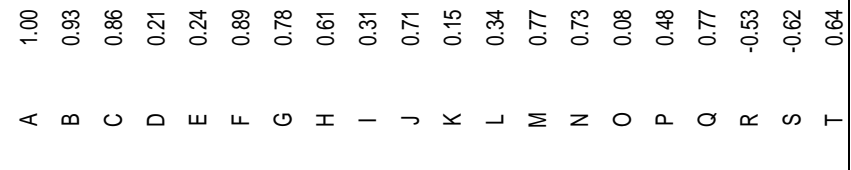 \\
\hline
\end{tabular}


Jednak S. et al.: The Effects of Economic Activities Diversification on Development...

The model (6) is used with the data described above in order to obtain the efficient frontier. The upper limits for the expected growth rate vary from $10.5 \%$ to $15 \%$ with increments of $0.5 \%$. Thus 12 different values of parameter R in model (6) are obtained and, consequently, 12 particular model's instances. Each of the 12 optimal solutions is one point of efficient frontier where $x$-axis and $y$-axis represent the optimal value of objective function and value of parameter $R$ in (6), respectively. Frontline systems Excel solver is used for optimization. Figure 2 presents the efficient frontier, while Figure 3 shows the composition of activities along the efficient frontier.

Figure 2. The efficient frontier

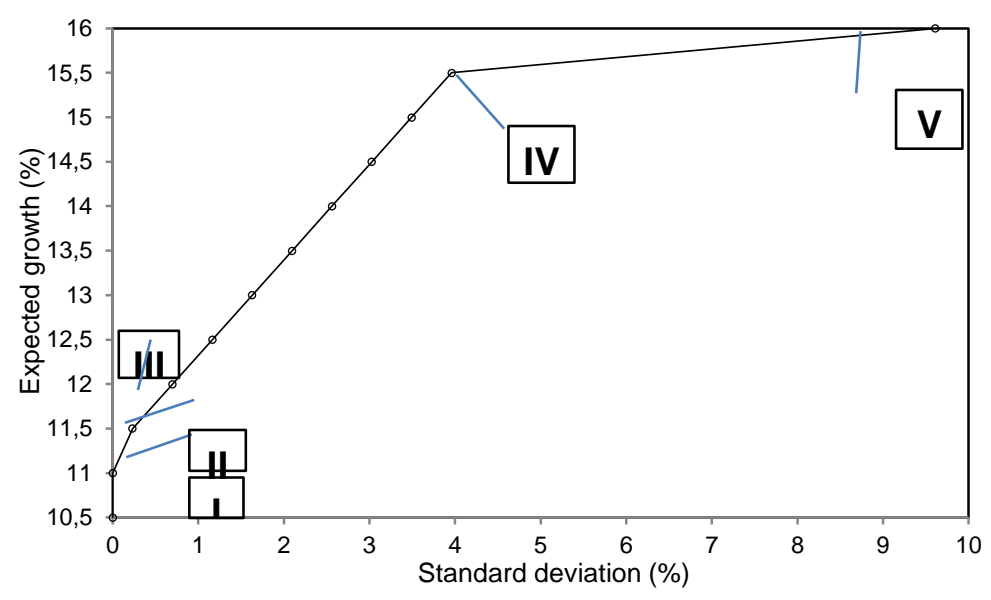

Figure 3. Expected growth by economic activities along the efficient frontier

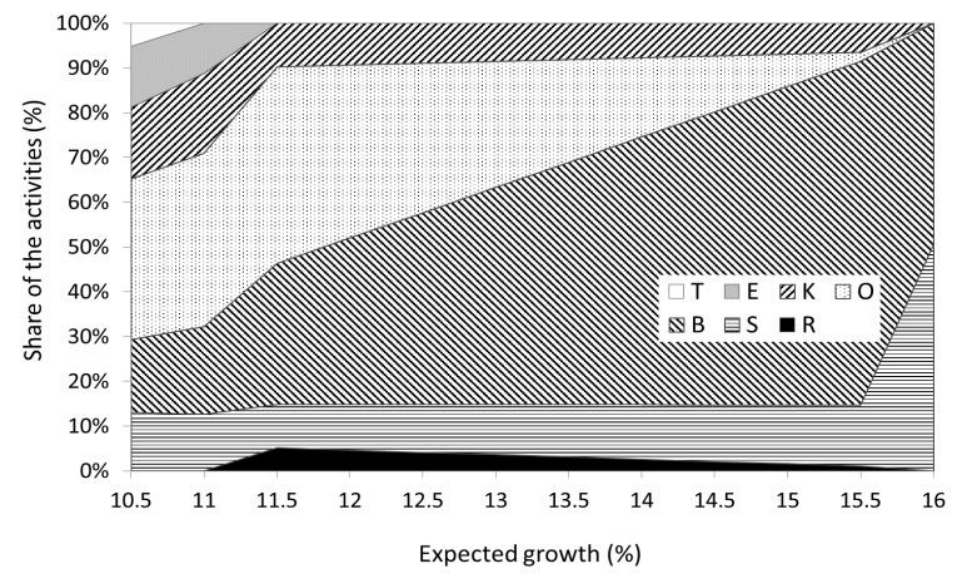


Jednak S. et al.: The Effects of Economic Activities Diversification on Development...

For the small risk, the expected growth is $11 \%$ or lower (points I and II on the efficient frontier in Figure 2). In these cases, the order of magnitude of standard deviation is $10^{-4}$ and seven economic activities ( $\mathrm{T}, \mathrm{E}, \mathrm{K}, \mathrm{O}, \mathrm{B}, \mathrm{S}$ and $\mathrm{R}$ ) are diversified.

The interesting parts of efficient frontier are the points from III to IV where the efficient frontier is almost linear. There, five economic activities are diversified (Figure 3): Arts, entertainment and recreation (R), Other service activities (S), Mining and quarrying (B), Public administration and defence; compulsory social security $(\mathrm{O})$, and Financial and insurance activities $(\mathrm{K})$. Moving along the efficient frontier, Mining and quarrying (B) gradually increases its share in the portfolio from $31,6 \%$ in to $76,76 \%$, due to its high growth rate. Along with this increase, the share of Public administration and defence; compulsory social security $(O)$ is significantly decreased from $43,86 \%$ to $1,92 \%$, since it has small growth rate. In III-IV part of the efficient frontier, two mentioned economic activities cover in average $77 \%$ of the optimal portfolios. Other service activities and Financial and insurance activities (K) remain almost constant at the share levels of approximately $11,5 \%$ and $8 \%$, respectively, while the share of Arts, entertainment and recreation $(R)$ is the smallest and gradually decrease from $5 \%$ to $1,1 \%$.

A further increase of growth rate is possible only with a significant increasing of risk. The point $\mathrm{V}$ on the efficient frontier in Figure 3 represents the optimal portfolio with standard deviation equal to $9.61 \%$. This risk is 2.4 times higher than the risk in point IV but causes only $0.5 \%$ higher growth rate.

Diversification has been conducted on seven economic activities. It can be argued that the optimal portfolios with different standard deviation (risks) are activities Mining and quarrying (B) and Public administration and defence; Compulsory social Security $(\mathrm{O})$. These two activities provide the best balance between growth and security regarding GVA. In this way these activities should have some impact on achieving economic growth. However, those activities are not the most developed in Serbia and its have not seen as key activities for obtaining the growth.

Research questions 4: Which economic activities should be invested in?

Strategies for economic growth and development of Serbia suggest that economic growth can be achieved by investing in infrastructure, power sector, ICT sector, education, financial sector and agricultural sector. The results achieved by analysis of the economic activities for the observed period show that investments should be directed towards Mining and quarrying (B), Public administration and defence; compulsory social security (O), Other service activities (S), Financial and insurance activities (K), Arts, entertainment and recreation $(R)$, because they provide balance between growth and security regarding GVA and employment in Serbian economic 
Jednak S. et al.: The Effects of Economic Activities Diversification on Development...

activities. The analysis showed that surprisingly quite different economic activities given in the Serbian development strategies and economic activities that are obtained through research in this paper. The only activity which coincided is financial activity. The research of this paper showed that investments should be directed mainly to the service economic activities.

\section{Conclusion}

Different economic activities enable economic growth and development. Depending on the available natural resources, physical and human capital economic growth, certain economic activities are being developed that represent targets activities for development. Predominant economic activities in less-developed and developing countries are agriculture and industry, and their growth is based on natural resources. However, while the level of development rises, the sectoral structure changes, the share of industry sector increases, and the share of agriculture in GDP drops (Punnyasavatsut and Coxhead, 2002; Arandjelovic et al., 2013, Savic, 2014). Highly developed countries mostly invest in service sector. Efficient allocations of the available resources, along with the change of institutional structure, are preconditions for obtaining development. At the beginning of development, sectoral diversification increases, but along with development sectoral diversity starts to concentrate i.e. to be more specialized (Imbs and Wacziarg, 2003). Moreover, each economy has comparative advantages and specialization in some economic activities. However, due to daily imbalances and changes there is a need for diversification. The research conducted in this work is the analysis of effect of economic activities structure and diversification on development in Serbia. The results show that economic activities structure and diversification have positive influence on economic growth and development. The largest share of total GVA belongs to Manufacturing (C), Wholesale and retail trade; repair of motor vehicles and motorcycles $G$ ), Real estate activities (L) and Agriculture, forestry and fishing (A). Also, a correlation was found between economic activities and the correlation vary from highly positive 0.98 (Manufacturing $(\mathrm{C})$ and Construction $(F)$ ) to highly negative 0.9 (Real estate activities (L) and Public administration and defence; compulsory social security $(\mathrm{O})$ ). Moreover, the highest annual GVA growth rates are in economic activities: Other service activities (S) and Mining and quarrying (B), but they have just a small share in GVA. On the contrary, economic activities with the highest share are: Manufacturing (C), Real estate activities $(L)$ and Wholesale and retail trade; repair of motor vehicles and motorcycles $(\mathrm{G})$, but have the smallest growth rates. To sum up, investments should be directed towards service based activities - Public administration and defence; compulsory social security $(\mathrm{O})$, Financial and insurance activities (K), Arts, entertainment and recreation (R), Other service 
Jednak S. et al.: The Effects of Economic Activities Diversification on Development...

activities (S) and Mining and quarrying (B)), because they provide a balance between growth and security regarding GVA in Serbian economic activities. These results show different economic activities which should be invested in than the Serbian national strategies of development suggest. The paper analysis is based on post-period data of contribution of economic activities to the total GVA, employment increase in each economic activity and risk of investments into economic activities. However, the Serbian national strategies of development consider recommendations of international organizations about key and common sectors and economic activities as drivers of economic growth and development. According to this, in our further work, the models could be expanded by including weights or lower bounds for investments in economic activities. Also, our future work could deal with the regional development and diversification of Serbia while applying Markowitz Mean-Variance Portfolio Theory. Furthermore, it would be interesting to apply this approach to another developing country, similar to the observed one and to find out whether the results would also be similar.

\section{References}

Alonso-Carrera, J., \& Raurich, X. (2010). Growth, sectoral composition and the evolution of income levels. Journal of Economic Dynamic and Control, 34(12), 2440-2460.

Arandjelovic, Z., Petrovic Randjelovic, M. Marjanovic, V. (2013). Structural changes in the light of new industrial strategy. Ekonomika preduzeca 61, 373-385.

Barry, F., \& Kearney, C. (2006). MNEs and industrial structure in host countries: a portfolio analysis of Irish manufacturing. Journal of International Business Studies, 37, 392-406.

Brewery, H.L. (1985). Measures of Diversification: Predictors of Regional Economic Instability. Journal of Regional Science, 25(3), 463-470.

Cadot, O., Carrere, C., Strauss-Kahn, V. (2013). Trade Diversification, income and growth: What do we know? Journal of Economic Surveys, 27(4), 790-812.

Cimoli M., \& Katz J. (2003). Structural reforms, technological gaps and economic development: a Latin American perspective. Industrial and Corporate Change, 12(1), 387-411.

Conroy, M.E. (1974). Alternative Strategies for Regional Industrial Diversification. Journal of Regional Science, 14(1), 31-46

Cornuejols, G., \& Tütüncü, R. (2011). Optimization Methods in Finance, Cambridge, New York

Cucchiella, F., D’Adamo, I., Gastaldi, M. (2012). Modeling optimal investments with portfolio analysis in electricity markets. Energy Education Science and Technology Part A: Energy Science and Research, 30(1), 673-692

Cvetkovic-Lecic, D., Atanasov, N,, Babarogic, S. (2010). An Algorithm for Customer Order Fulfillment in a Make-to-Stock Manufacturing System. International Journal of Computers, Communication and Control, V(5), 783-791. 
Jednak S. et al.: The Effects of Economic Activities Diversification on Development...

Cypher James, M., Dietz James, L. (2009). The Process of Economic Development, 3th Editon, Routledge, New York

Djordjević, M., \& Veselinovic, P. (2010). Razvojne karakteristike srpske ekonomije u periodu tranzicije. Visa poslovna skola, Novi Sad

Eichholtz, P.M.A., Hoesli, M. (1995). Real estate portfolio diversification by property type and region. Journal of Property Finance, 6(3), 39-59.

Fabozzi, F.J., Kolm, P.N., Pachamanova, D.A., Focardi, S.M. (2007). Robust Portfolio Optimization and Management, John Wiley \& Sons, Inc., New Jersey

Fu, S., Dong, X., Chai, G. (2010). Industry specialization, diversification, churning and unemployment in Chinese cities. China Economic Review, 21(4), 508-520.

Gilchrist, D.A, Louis, St., Larry, V. (1995). Consistency of regional industrial diversification and air quality process. Economic Systems Research, 7(2), 173.

Group of authors. (2010). Postkrizni model ekonomskog rasta i razvoja Srbije 20112020, Ekonomski institute i FREN, Beograd, Srbija Retrieved from http://www.kss.org.rs/doc/1102 makroekonomska proj razv Srbije 20112020.pdf

Hesse, H. (2009). Export Diversification and Economic Growth. Working paper no.21. Commission on Growth and Development. Retrived from http://213.154.74.164/invenio/record/18458/files/hesse.pdf

Imbs, J., \& Wacziarg, R. (2003). Stages of Diversification. American Economic Review, 93(1), 63-86.

IMF staff. (2014). Sustaining long-run growth and macroeconomic stability in lowincome countries - the role of structural transformation and diversification. IMF policy paper. Retrieved from http://www.imf.org/external/np/pp/eng/2014/030514.pdf

Iordan, M., \& Chilian, M.N. (2014). The sectoral structures in Romania, its regions and the EU countries - key features of economic and social cohesion. Procedia Economics and Finance, 8, 397-406.

Izveštaj o razvoju Srbije 2010. (2010). Ministarstvo finansija i privrede. Retrieved from http://mfp.gov.rs/UserFiles/File/dokumenti/IZVESTAJ\%200\%20RAZVOJU\%20S RBIJE\%202010.pdf

Jaimovich, E. (2011). Sectoral differentiation, allocation of talent, and financial development. Journal of Development Economics, 96, 47-60.

Jednak S., Makajic Nikolic D., Kragulj D., Vujosevic M. (2014). Economic Activities Structure and Development: Evidence from Serbia, Management, 71, 29-38.

Jednak, S. (2012). Development of a knowledge based economy-opportunities and challenges, Belgrade, Zaduzbina Andrejevic.

Junning, C., \& Leung, P.S. (2006). Growth and Stability of Agricultural Production in Hawaii: A Portfolio Analysis, Economic Issues \#El-9, Cooperative Extension Service, College of Tropical Agriculture and Human Resources, University of Hawai'i at Manoa, http://scholarspace.manoa.hawaii.edu/handle/10125/2854

Lande, P.S. (1994). Regional Industrial Structure and Economic Growth and Instability. Journal of Regional Science, 34(3), 343-360.

Louis, L.V.St. (1980). A measure of regional diversification and efficiency. The Annals of Regional Science, 14(1), 21-30

Markowitz, H. (1952). Portfolio Selection. The Journal of Finance, 7(1), 77-91.

Masol, O., \& Banal-Estanol, A. (2014). Export diversification through resource-based industrialization: the case of natural gas. European Journal of Operational Research, 237, 1067-1082. 
Jednak S. et al.: The Effects of Economic Activities Diversification on Development...

Milenkovic, N., Vukmirovic, J., Bulajic, M., Radojicic, Z. (2014). A multivariate approach in measuring socio-economic development of MENA countries. Economic Modelling, 38, 604-608.

Murshed, S.M., \& Serino, L.A. (2011). The pattern of specialiyation and economic growth: The resource curse hypothesis. Structural Change and Economic Dynamics, 22 (2), 151-161.

Nacrt fiskalne strategije za 2013. godinu sa projekcijama za 2014. i 2015.godinu, Ministarstvo finansija i privrede Republike Srbije, Retrieved from http://www.mfp.gov.rs/pages/article.php?id=8626

Noseleit, F. (2013). Entrepreneurship, structural change and economic growth. Journal of Evolutionary Economics, 23, 735-766.

Punyasavatsut, C., \& Coxhead, I. (2002). On the Decline of Agriculture in Developing Countries: A Reinterpretation of the Evidence. Staff Paper No. 457, Agricultural and Applied Economics, 47

Rodoulis, N. (2010). Evaluation of Cyprus' Electricity Generation Planning Using MeanVariance Portfolio Theory. Cyprus Economic Policy Review. 4(2), 25-42.

Savic, Lj. (2014). New Industrialization in Serbia - Reality or Delusion. Management, 70, 59-64.

Shediac, R., Moujaes, C.N., Najjar, M.R., Ghaleb, J. (2011). Resilient, Stable, Sustainable: The Benefits of Economic Diversification. Booz\&co. Retrieved from http://www.strategyand.pwc.com/media/file/Strategyand-Resilient-StableSustainable-Benefits-Economic-Diversification.pdf

Siegel, P.B., Johnson, T.G., Alwang, G. (1995). Regional Economic Diversity and Diversification. Growth and Change, 26(2), 261-284.

Spelman, W. (2006). Growth, Stability, and the Urban Portfolio. Economic Development Quarterly, 20, 299-316.

The World Bank (2012). Republic of Serbia, The Road to Prosperity: Productivity and Export. Country Economic Memorandum. Report No. 65845-YF Retrieved from http://www-

wds.worldbank.org/external/default/WDSContentServer/WDSP/IB/2012/08/23/00 $033303820120823010132 /$ Rendered/PDF/658450ESW0v10Y0C0disclosed080 210120.pdf

Westner, G., \& Madlener, R. (2010). The benefit of regional diversification of cogeneration investments in Europe: A mean-variance portfolio analysis. Energy Policy, 38, 7911-7920.

Westner, G., \& Madlener, R. (2011). Development of cogeneration in Germany: A mean-variance portfolio analysis of individual technology's prospects in view of the new regulatory framework. Energy, 36, 5301-5313. 